\title{
Determination of Theoretical and Methodological Principles of Teaching Multimedia Arrangement of Future Music Teachers in the Process of Professional Training
}

\author{
Stepanov Volodymyr \\ ORCID ID https://orcid.org/0000-0002-3018-4483 \\ Postgraduate student \\ Dragomanov National Pedagogical University (Ukraine, Kyiv)
}

\begin{abstract}
In the article the importance of professional training of students in order to ensure a comprehensive readiness for future pedagogical activities is actualized. The researches of scientists concerning the professional training of future music teachers are analyzed and summarized. It is noted that the professional training of future music teachers is focused on the modernization and optimization of the educational process. The interpretation of the concept of theoretical and methodical principles is researched and our own interpretation of the concept of «theoretical and methodical principles of teaching multimedia arrangement of future music teachers» is given. The basic components of theoretical and methodical principles of teaching multimedia arrangement of future music teachers in the process of professional training: scientific approaches, principles and methods are determined. The issue of integration of musical-performing disciplines as an optimal organization of the pedagogical process on the basis of inter-subjective interaction is emphasized. The essence of the methodology of teaching multimedia arrangement of future music teachers is defined, the main directions of educational work which will affect the quality of their professional training in general are outlined.
\end{abstract}

Key words: professional training, theoretical and methodological principles, integration, training of multimedia arrangements, future music teachers.

Актуальність досліджсення. У відповідності до нових вимог сучасності актуалізуються питання фахової підготовки майбутніх учителів, яка в контексті реформування освіти, спрямованого на подолання протиріч між традиційними формами й методами навчання та новими можливостями, що пов'язані $з$ появою нових форм інформації, нового освітнього середовища [5], потребує розроблення i впровадження нових підходів до методики навчання студентів з метою забезпечення всебічної готовності до майбутньої педагогічної діяльності.

У контексті нашого дослідження метою даної статті визначено розгляд теоретико-методичних засад навчання мультимедійного аранжування майбутніх учителів музики в процесі фахової підготовки.

Виклад основного матеріалу. Визначення поняття «підготовка» спирається на досвід системного дослідження освіти та педосвіти як складноорганізованих 
соціокультурних феноменів і пов'язано 3 науковими доробками В. Андрущенка, Г. Балла, Б. Гершунського, О. Глузмана, В. Лугового, О. Олексюк, О. Шевнюк та ін.. Варто зауважити, що сучасні стандарти вищої освіти акцентують увагу на інтеграції навчальних дисциплін, що вимагає розроблення теоретичних i практичних засад моделювання дидактичного процесу, його інформатизації, з'ясування механізму реалізації взаємозв'язків між дисциплінами з урахуванням професійної спрямованості в ході добору їхнього змісту [7, с. 4].

Інтеграцію мистецтв у фаховій підготовці майбутніх учителів музики розглянуто Г. Бродським, О. Рудницькою, О. Хижною, І. Шевченко. Питання реалізації міжпредметних знань розглянуті Л. Варнавською, Т. Латишевою. Питання інтеграції музично-теоретичної підготовки досліджували О. Комаровська [13], I. Малашевська, Г. Побережна, Т. Щериця, Ю. Локарєва. Інтеграцію музично-виконавської підготовки розглядали В. Лабунець, Ж. Карташова, С. Проворова, О. Щолокова [12; 14].

Науковими дослідженнями останніх років (О. Барицька, Л. Варнавська, Л. Гаврілова, Ю. Дворник, В. Луценко, Л. Масол, Н. Новікова, Н. Сушкевич, В. Шинкаренко, О. Чайковська, М. Чембержі та ін.) доведено, що використання мультимедійних технологій уможливлює застосування нових методів, форм та засобів організації навчальної діяльності. Під поняттям «мультимедійні технології» науковці розуміють комплекс інформаційних технологій (Н. Новикова), велику «галузь знань, що інтегрує елементарну теорію музики, сольфеджіо, ансамбль, оркестр, вокальне мистецтво, аранжування, читання оркестрових партитур, інструментування й можливості сучасних комп'ютерних технологій» [11, с. 338].

Визначення мультимедійної технології як технології, що «окреслює порядок розробки, функціонування та застосування засобів обробки інформації різних модальностей» та мультимедійного уроку, «на якому використовують багатосередовищне подання інформації за допомогою технічних засобів, перш за все комп'ютера» подані М. Ляшком [3, с.101; 14; 15; 16].

У довідникових джерелах знаходимо декілька значень поняття «засада», серед яких: «основа чогось» (тобто, те, на чому щось базується), «вихідне, головне положення, принципи» і спосіб, метод здійснення чого-небудь» [1, с. 41]. Методика навчального предмета досліджує закономірності вивчення предмета і включає 
вироблення методів, методичних засобів і організаційних форм навчання (відповідно до змісту і завдань), а у вузькому розумінні - учення про методи навчання [8, с. 20]. Поняття «теорія» в Українському педагогічному словнику трактується як «сукупність ідей, поглядів, концепцій, вчень, уявлень про об’єктивну дійсність». Практична діяльність «осмислюється, організовується, спрямовується теорією» [8, с. 328].

Отже, теоретико-методичні засади навчання мультимедійного аранжування майбутніх учителів музики розуміємо як сукупність вихідних концептуальних положень щодо обгрунтування і визначення основоположних принципів, методів, форм навчання мультимедійного аранжування, визначених науковими підходами.

Навчання мультимедійного аранжування ми розуміємо як активний умотивований процес інтегрованої взаємодіі навчально-пізнавальної, практичної музично-творчої діяльності, спрямованої на створення нового якісного продукту аранжування музичного твору - на основі узагальнення теоретичних знань, збагачення практичного (слухацького) досвіду та оволодіння засобами мультимедіа. Очевидно, що якість фахової підготовки майбутніх учителів музики в наш час великою мірою залежить саме від оволодіння сучасними освітніми мультимедійними технологіями.

Через що, виникає необхідність розробки методики навчання мультимедійного аранжування майбутніх учителів музики, що позначиться на якості їхньої фахової підготовки у цілому. Сутність методики полягає у підтримці мотивації до навчання мультимедійного аранжування, актуалізації музично-теоретичних знань і практичнотворчих умінь, розвитку навичок отримання інформації з різних джерел (Інтернет включно), умінь використовувати засоби мультимедіа у процесі створення творчого продукту (аранжування музичних творів), оскільки їх застосування суттєво розширює межі музично-творчої діяльності вчителя музики і відкриває нові можливості для фахової самореалізації в інформаційному суспільстві.

Основу авторської методики становлять визначені нами напрямки роботи. Першим $\epsilon$ спрямування на набуття слухацького досвіду, розвитком у студентів музичного слуху (гармонічного, поліфонічного, тембрового, внутрішнього), здатності знаходити, відчувати, розуміти структурні елементи музичної мови, стиль, жанр, епоху, особливості творчого почерку композитора, на закріплення інтегрованих знань, умінь i навичок з теоретичних дисциплін. 
Наступний напрямок забезпечує розвиток музично-інтонаційного, образноасоціативного, поліфонічного, креативного мислення студентів, навичок імпровізації, самоаналізу, самооцінювання, самокритики та саморозвитку, формування музичноестетичного смаку. Наступні два напрямки роботи спрямовано на отримання знань, умінь і навичок щодо усіх видів аранжування (інструментовки, оркестровки, обробок тощо) та роботи з комп’ютерними програмами, спираючись на набутий у процесі опанування дисципліни «Музична інформатика» досвід.

Складовими методики виступили такі методи навчання: словесні (акроматичні та діалогічні (евристичні) методи навчання, зокрема, евристична бесіда, спрямована на розвиток музично-творчого, образно-асоціативного мислення студентів; лекції, в тому числі: лекція-екскурсія (віртуальна), лекція-візуалізація); наочні (наочно-слуховий та наочно-зоровий); інтерактивні («мозковий штурм», метод безперервної шкали думок, створення пошукових ситуацій, метод проектів); дієво-практичні (метод творчих завдань, метод інтроспекції, презентацій готового мультимедійного продукту), методи аналітично-мисленнєвої діяльності (аналізу, синтезу, порівняння, метод асоціацій, пізнання та художнього сприйняття, герменевтичного аналізу, висновків, узагальнення), методи оцінки і стимулювання (що включають самооцінку), створення ситуацій успіху, самоконтролю.

Означена методика потребує опори на особистісний, аксіологічний, акмеологічний, компетентнісний, діяльнісний підходи та герменевтичний як базисний. Аранжування музичного твору потребує від студентів детального вивчення музичного тексту, власна інтерпретація якого має бути кінцевим результатом їхньої творчої роботи. Тому у навчанні аранжуванню майбутніх учителів музики великого значення набуває герменевтична методологія, зокрема, принцип герменевтичного кола, екзистенційні діалоги, емпатійне проникнення у світ іншої людини, саморозуміння тощо. Серед особливостей герменевтичної методології необхідно підкреслити пї діалоговий характер. Отже, герменевтика як теорія розуміння та інтерпретації музичних творів $є$ методологічною основою навчання майбутніх учителів музики аранжуванню у процесі фахової підготовки.

Цілісний розвиток особистості, суб’єкт-суб'єктні взаємовідносини у процесі навчання забезпечуються з позицій особистісного підходу. Особистісний підхід у 
процесі навчання мультимедійного аранжування забезпечує створення відповідних умов для діагностики, а потім і ефективного розвитку творчого потенціалу особистості, враховуючи різнорівневу інформаційну та музичну підготовку студентів, загальний рівень освіченості, сформованості в них художнього смаку.

Аксіологічний підхід характеризується ставленням до майбутньої професії, розумінням ціннісних орієнтирів обраної професії (що передбачає сформованість ціннісно-світоглядних мистецьких орієнтацій), наявністю потреби стати кваліфікованим викладачем-музикантом (який зможе створити, за необхідності, власне художньо якісне аранжування музичного твору), наявністю потреби вдосконалювати фахову компетентність. Формування цих якостей сприяє активному та ефективному,

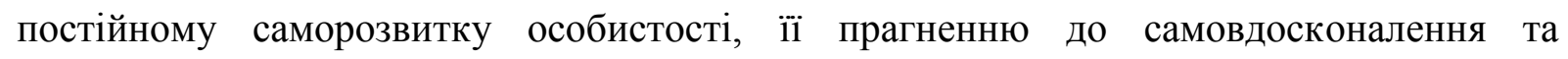
самоактуалізації, що визначається акмеологічним підходом, завдяки якому майбутній вчитель музики спрямовується на «прогноз якісного результату в його підготовці до практичної діяльності, ... на вивчення акмевершин у музично-педагогічній роботі, на проектування методичних моделей професійної діяльності» [9, с. 4-5].

Зважаючи на те, що на сучасному етапі дещо змінюється розуміння ролі знань завдяки компетентнісному підходу до освіти (знання підпорядковуються умінням), навчання мультимедійного аранжування студентів вважаємо за необхідне розглядати 3 позицій компетентнісного підходу, актуалізуючи проблему формування фахових компетентностей, серед яких в межах нашого дослідження виділяємо інформаційну та музично-естетичну компетентності. У зв’язку з цим, виникає необхідність опори на діяльнісний підхід до навчання мультимедійного аранжування, при якому знання стають не метою навчання, а його засобом: знання засвоюються не для підвищення ерудиції, а для того, щоб здійснювати діяльність (Г. Атанов).

Зміна освітньої парадигми вимагає відображення в спрямованості професійного розвитку майбутнього вчителя, перегляду пріоритетів, що лежать в основі змісту мистецької освіти, що породжує необхідність концептуального переосмислення, подолання інертності навчально-виховного процесу у вищій школі, зазначає О. Хижна, вбачаючи розв'язання цієї проблеми в переосмисленні традиційного підходу до навчально-виховного процесу, зокрема, переосмисленні принципів [10]. 
Оскільки принципи, як основні положення будь-якого навчання, в тому числі і музичного, визначають сутність, зміст, провідні вимоги до взаємодії викладача та студентів, розділяючи думку О. Хижної, у контексті навчання мультимедійного аранжування, вважаємо за важливе дотримуватися загально-дидактичних та специфічних принципів навчання з опорою на останні.

Одним з основоположних виділяємо принцип музично-естетичного спрямування навчання. Музично-естетична спрямованість охоплює увесь зміст роботи: від формування позитивної мотивації навчальної діяльності до створення власного творчого продукту. Естетичні потреби особистості, що спрямовують на свідоме та глибоке розуміння музичного мистецтва, виступають основним мотивом навчальної діяльності в цій галузі.

Дотримання принципу діалогізації $є$ важливим, оскільки діалогічність у особистісному спілкуванні створює умови для творчих взаємовідносин. За своєю сутністю музичне мистецтво діалогічне (О. Олексюк, О. Рудницька та ін.) Мета такого діалогу створити цілісне розуміння музичного твору. Специфіка навчального діалогу визначається цілями, умовами та обставинами взаємодії.

Принцип урахування індивідуальних особливостей у застосуванні колективних форм роботи характеризує діяльність викладача й звернений до процесу навчання мультимедійного аранжування, як і будь-якого навчання, з виявленням особливостей навчання та розвитку кожного студента, спостереження за засвоєнням змістового музичного матеріалу та його творчим застосуванням. Важливим $\epsilon$ дотримання принципу акмеологічного супроводу студента в його духовному становленні, підпорядкованому постійному особистісному зростанню, та принципу індивідуального підходу з урахуванням різнорівневої музично-теоретичної підготовки та слухацького досвіду студентів (щодо інтерпретації музичних творів).

У ході експериментальної роботи ми дотримувалися також принципу відповідності творчих завдань змісту та об’єму навчальної діяльності, що передбачає уміння застосовувати інтегровані знання з музично-теоретичних дисциплін та засоби мультимедіа у практичній діяльності з метою формування практично-фахових умінь та навичок, та принцип творчої самореалізації особистості. 
Велике значення мають пов'язані між собою принципи організації навчального процесу з акцентом на самоосвіту студентів; спрямованості на їх інтелектуальний розвиток. Виокремленні нами принципи базуються на закономірностях музичнопедагогічної освіти, відображають внутрішню сутність процесу навчання мультимедійного аранжування.

Висновки. Отже, визначення оптимальних теоретико-методичних засад навчання мультимедійного аранжування майбутніх учителів музики сприяє вирішенню однієї з головних суперечностей між якістю знань в контексті традиційного підходу до змісту фахової підготовки майбутніх учителів музики, рівнем практичних умінь, яких вимагає від фахівця майбутня музично-педагогічна діяльність та освітніми завданнями розвитку і становлення творчої особистості майбутнього вчителя музики.

\section{References}

1. Velykyi tlumachnyy slovnyk suchasnoyi ukrayins koyi movy [Great explanatory dictionary of modern Ukrainian language] (z dod. i dopov.) / uklad. i holov. red. V.T. Busel. Kyiv: Irpin': VTF «Perun», 2005. 1728 p.

2. Yeremenko O.V. Teoriya i metodyka pidhotovky mahistriv muzychnoho mystetstva $v$ pedahohichnykh universytetakh [Theory and methodology of preparation of masters of musical art in pedagogical universities]: avtoref. dys. na zdobuttya nauk. stupenya dokt. ped. nauk: spets. 13.00.02 - Teoriya ta metodyka muzychnoho navchannya. Kyiv: NPU imeni M.P. Dragomanova, 2010. 45 p.

3. Lyashko M. Mul'tymediyni tekhnolohiyi yak innovatsiyna skladova muzychnoho navchannya i vykhovannya [Multimedia technologies as an innovative component of musical education and upbringing]. Humanitarnyy visnyk, 2014. No 33. P. 96-110.

4. Petko L.V. Vykhovnyi potentsial metodu sytuatsiinoho analizu ("Case study» method) u formuvanni profesiino oriientovanoho inshomovnoho navchalnoho seredovyshcha $v$ umovakh universytetu [Educational potential of the «Case study» method for the forming of the professionally oriented foreign language teaching environment in the conditions of university]. Naukovyi chasopys NPU imeni M.D.Drahomanova. Seriia 17. Teoriia i praktyka navchannia ta vykhovannia : zb. nauk. pr.;Kyiv: Vyd-vo NPU imeni M.P.Drahomanova, 2015. Issue 27. P. 133-140.

5. Petko L.V. Informatsiyno-navchalne seredovische yak umova formuvannya profesiyno orientovanogo inshomovnogo navchalnogo seredovischa v umovah universitetu [Information and teaching environment as a condition of professionally oriented foreign language teaching environments formation in the terms of the university]. Informatsiyni tehnologiyi u profesiyniy diyalnosti: Tr. IX Vseukrayinskoyi nauk.-prakt. konf., Ryvnenskiy derzhavniy gumanytarniy un-t, 25 bereznya 2015 r. Ryvne, 2015. P. 89-91. 
6. Petko, L. V. Filmy inozemnoiu movoiu u formuvanni POINS dlia studentiv-biolohiv [The foreign-language films in forming professionally oriented foreign language learning environment for students in Biology]. Krytychnyi pidkhid u vykladanni pryrodnychykh dystsyplin : materialy Mizhnarodnoi naukovo-metodychnoi konferentsii, 14 lystopada 2018 roku / ukl.: O.P. Halai [ta in.]. Kyiv: Vyd-vo NPU imeni M. P. Drahomanova, 2018. P. 118-124.

7. Timets' O.V. Teoriya $i$ praktyka formuvannya fakhovoyi kompetentnosti maybutn'oho vchytelya heohrafiyi u protsesi profesiynoyi pidhotovky [Theory and practice of forming the professional competence of the future teacher of geography in the process of professional training]: avtoref. dys. na zdobuttya nauk. stupenya dokt. ped. nauk: spets. 13.00.04 - teoriya i metodyka profesiynoyi osvity. - Cherkasy:

Cherkas'kyy nats. un-t imeni Bohdana Khmel'nyts'koho, 2011. 43 p.

8. Ukrayinskyi pedahohichnyy slovnyk [Ukrainian Pedagogical Dictionary ] / red. S.U. Honcharenko. Kyiv: Lybid', 1997. 376 p.

9. Fedoryshyn V.I. Teoriya ta metodyka fakhovoyi pidhotovky maybutnikh uchyteliv muzyky na akmeolohichnykh zasadakh. [Theory and methodology of professional training of future music teachers on the basis of acmeology]: avtoref. dys. na zdobuttya nauk. stupenya dokt. ped. nauk: spets. 13.00.02 - Teoriya ta metodyka muzychnoho navchannya. Kyiv: NPU imeni M.P.Dragomanova, 2014. 45 p.

10. Khyzhna O. Filosofs 'ko-synerhetychnyy kontekst pidhotovky maybutn'oho vchytelya do zabezpechennya osnov mystets koyi osvity uchniv pochatkovoyi shkoly [ The philosophical and synergistic context of preparing a future teacher to provide the basics of artistic education for elementary school students]. Psykholoho-pedahohichni problemy sil's 'koyi shkoly. 2010, Issue 34. P. 148-150.

11. Shynkarenko V. Mul'tymediyni tekhnolohiyi yak zasib kompetentnisnoho stanovlennya maybutnikh uchyteliv muzyky [Multimedia technologies as a means of competent formation of future music teachers ]. Humanitarnyy visnyk Derzhavnoho vyshchoho navchal'noho zakladu «Pereyaslav-Khmel'nyts kyy derzhavnyy pedahohichnyy universytet imeni H.S. Skovorody». Pedahohika. Psykholohiya. Filosofiya. - PereyaslavKhmel'nyts'kyy, 2013. Issue. 28 (1). P. 336-340.

12. Chen Kai, Shcholokova Olga. Methodological basis of the future musicianseducators' performance-educational activity. Intellectual Archive. - Toronto : Shiny Word.Corp. (Canada). 2018. (May/June). Vol. 7. No. 3. PP. 5-68.

13. Komarovska Oksana, Huang Hanjie. Readiness for stage partnership in vocalensemble performance as a vector in professional training music teacher. Intellectual Archive. - Toronto: Shiny Word.Corp. (Canada). 2018. (September/October). Vol. 7. No. 5. PP. 66-74. (https://doi.org/10.32370/2018_09_7)

14. Shcholokova O. P. Art and pedagogical designing as a means of improvement of music teacher's professional preparing. Economics, management, law: socio-economical aspects of development: Collection of scientific articles. Volum 2. - Edizioni Magi - Roma, Italy. 2016. P. 265-268 


\section{Translation of the Title, Abstract and References to the Author's Language}

\section{УДК 378.011.3 - 51:78}

Степанов Володимир. Визначення теоретико-методичних засад навчання мультимедійного аранжування майбутніх учителів музики в процесі фахової підготовки.

У статті актуалізовано значення фахової підготовки студентів. Проаналізовано і узагальнено погляди науковців 3 досліджуваної проблеми. Досліджено трактування поняття теоретико-методичних засад та подано власне трактування поняття «теоретикометодичні засади навчання мультимедійного аранжування майбутніх учителів музики», визначено основні складові теоретико-методичних засад навчання мультимедійного аранжування майбутніх учителів музики в процесі фахової підготовки: наукові підходи, принципи, методи. Акцентовано питання інтеграції музично-виконавських дисциплін як оптимальної організації педагогічного процесу на основі міжсуб'єктної взаємодії. Розкрито сутність методики навчання мультимедійного аранжування майбутніх учителів музики; окреслено основні напрямки навчальної роботи, що сприятимуть якості їхньої фахової підготовки у цілому.

Ключові слова: фахова підготовка, теоретико-методичні засади, інтеграція, навчання мультимедійного аранжування, майбутні учителі музики.

\section{Лimepamypa}

1. Великий тлумачний словник сучасної української мови (з дод. і допов.) уклад. i голов. ред. В. Т. Бусел. - Київ: Ірпінь: ВТФ «Перун», 2005. 1728 с.

2. Сременко О. В. Теорія і методика підготовки магістрів музичного мистецтва в педагогічних університетах: автореф. дис. на здобуття наук. ступеня докт. пед. наук: спец. 13.00.02 - Теорія та методика музичного навчання / О.В. Єременко. - Київ: НПУ імені Драгоманова, 2010. 45 с.

3. Ляшко М. Мультимедійні технології як інноваційна складова музичного навчання і виховання. Гуманітарний вісник, 2014. № 33. С. 96-110.

4. Петько Л.В. Виховний потенціал методу ситуаційного аналізу («Case study» method) у формуванні професійно орієнтованого іншомовного навчального середовища в умовах університету. Науковий часопис НПУ імені М.Д. Драгоманова. Серія 17. Теорія і практика навчання та виховання : зб. наук. пр. ; за ред. академіка В.І.Бондаря. Київ: Вид-во НПУ імені М.П.Драгоманова, 2015. Вип. 27. С. 133-140.

5. Петько Л.В. Інформаційно-навчальне середовище як умова формування професійно орієнтованого іншомовного навчального середовища в умовах університету. Інформаційні технології у професійній діяльності: Тр. IX Всеукраїнської наук.-практ. конф., Рівненський державний гуманітарний ун-т, 25 березня 2015 р. Рівне, 2015. C. 89-91.

6. Петько, Л. В. Фільми іноземною мовою у формуванні ПОІНС для студентівбіологів. Критичний підхід у викладанні природничих дисциплін : матеріали Міжнародної науково-методичної конференції, 14 листопада 2018 року / укл. : О. П. Галай [та ін.]. Київ : Вид-во НПУ імені М. П. Драгоманова, 2018. С. 118-124. 
7. Тімець О.В. Теорія і практика формування фахової компетентності майбутнього вчителя географії у процесі професійної підготовки: автореф. дис. на здобуття наук. ступеня доктора пед. наук: 13.00.04 - Теорія і методика професійної освіти / О.В. Тімець - Черкаси: Черкаський національний ун-т імені Богдана Хмельницького. 2011. 43 с.

8. Український педагогічний словник / ред Гончаренко С. У. - Київ: Либідь, 1997. $376 \mathrm{c}$.

9. Федоришин B.I. Теорія та методика фахової підготовки майбутніх учителів музики на акмеологічних засадах: автореф. дис. на здобуття наук. ступеня докт. пед. наук : спец. 13.00.02 - Теорія та методика музичного навчання. Київ: НПУ імені Драгоманова, 2014. 45 с.

10. Хижна О. Філософсько-синергетичний контекст підготовки майбутнього вчителя до забезпечення основ мистецької освіти учнів початкової школи. Психолого-педагогічні проблеми сільської иколи. 2010. Вип. 34. С. 148-150.

11. Шинкаренко В. Мультимедійні технології як засіб компетентнісного становлення майбутніх учителів музики. Гуманітарний вісник Державного вищого навчального закладу «Переяслав-Хмельницький державний педагогічний університет імені Г.С. Сковороди». Педагогіка. Психологія. Філософія. - Переяслав-Хмельницький, 2013. Вип. 28 (1). С. 336-340.

12. Chen Kai, Shcholokova Olga. Methodological basis of the future musicianseducators' performance-educational activity. Intellectual Archive. - Toronto : Shiny Word.Corp. (Canada). 2018. (May/June). Vol. 7. No. 3. PP. 58-68.

13. Komarovska Oksana, Huang Hanjie. Readiness for stage partnership in vocal-ensemble performance as a vector in professional training music teacher. Intellectual Archive. Toronto: Shiny Word.Corp. (Canada). 2018. (September/October). Vol. 7. No. 5. PP. 66-74. (https://doi.org/10.32370/2018_09_7)

14. Shcholokova O.P. Art and pedagogical designing as a means of improvement of music teacher's professional preparing. Economics, management, law: socio-economical aspects of development: Collection of scientific articles. Volum 2. - Edizioni Magi - Roma, Italy. 2016. P. 265-268. 